Capítulo sometido a la dirección editorial del libro en 2008, posteriormente aceptado y publicado. Rogamos que, a efectos de divulgación, docencia y cita bibliográfica se acuda a la publicación impresa (u online de la propia editorial) y la cita sea esta:

MacInnes, J., Pérez Díaz, J. (2009), "Transformations of the World's Population: the Demographic Revolution." en Turner, B.S. -Ed-, The Routledge International Handbook of Globalization Studies: WileyBlackwell, pp. 137-161.

\title{
Transformations of the World's Population: the Demographic Revolution
}

Maclnnes, J., Pérez Díaz, J.

The institutional origins of global demography

Until about ten thousand years ago, when the agricultural revolution began, the global population of human beings probably numbered a few million. Settled agriculture allowed population to start rising steadily, but very slowly, so that by $\mathrm{AD}$ 1 it probably numbered 200-300 millions. It reached one billion around 1800, and two billion some time before the outbreak of the Second World War. The four billion mark was reached in 1960 and global population is currently around 6.7 billion (LiviBacci 2001) $)^{1}$. It has perhaps always been possible to imagine a global population of human beings, to describe it, albeit in such rudimentary terms, and even attribute different qualities and behaviour to it. The concept of the human species is a very old one, of course, and one which contemporary biology gives an ever more specific understanding and meaning to. However a specifically demographic understanding of the global human population, understood as an integrated population system, has until very recently never been more than a strictly theoretical proposition.

For a start, it was simply not possible to study global population, as there were no good sources of data about it. The figures cited above are intelligent guesswork based on extrapolation from limited sources. Moreover, until the efforts of the United Nations (UN) began at the end of the 1940s, there had been little interest in it.

\footnotetext{
${ }^{1}$ Unless otherwise stated the sources for data quoted in the text is the United Nations Population Division World Population Prospects 2006 revision Population Database, available at http://esa.un.org/unpp. More recent estimates, where available, have also been used.
} 
Demography is a relatively recent science born out of the information and surveillance needs of the modern nation state. Being a statistical discipline in the true sense of the word (Mackenzie 1981) it only developed with the appearance and consolidation of national statistical systems in the most advanced states towards the end of the $19^{\text {th }}$ century (Dupaqier 1985). Accordingly, as a discipline, its concept of population has almost always been banally nationalist (Billig 1995) in the strongest possible sense. It treated each state as comprising a population in its own right, and thus to the twin basic components of the 'demographic equation' - fertility (births) and mortality (deaths) were added those of in- and out- migration defined in terms of state boundaries.

Until the issue of global population growth first became a concern in the late 1940s, virtually the entire corpus of scientific literature addressed national state interests, or the application of such interests to lower level territorial administrative units - cities, counties, provinces and so on. This continues to be true. Indeed it is the territorial unit within which people live that has become demography's object of study, rather than population as a reproductive system. One result of this theoretical weakness, combined with its institutional dependence on the state, has been a tendency for demography to be driven by the prevailing fears and obsessions of the governing classes, concentrating on the proximate causes of any alarming trend in demographic phenomena (Foucault 1989; Teitelbaum and Winter 1985). There has rarely been any shortage of these.

Its birth as a modern discipline was closely bound up with eugenics (Mackenzie 1976; Soloway 1990) and in the early decades of the twentieth century many national demographies joined in the battle for higher fertility in the professional or 'fitter' classes, or for stronger population growth than that of rival states (Szreter 1996). There has also been a tendency to understand demographic behaviour in moral terms, resulting either in variants of catastophism, a tradition well established by Malthus's original Essay (1970), continued by Spengler's Decline of the West (1928) and culminating in Ehrlich's predictions of mass global famine in The Population Bomb (1968).

The establishment of what might be thought of as global demography both continued and challenged this tradition. Reliable statistical knowledge about global population had to wait until the creation of the United Nations in the aftermath of 
the Second World War, and the development of censuses across the entire planet by its Population Division (UNPD) established in 1946 (Caldwell and Caldwell 1986), although what was to become the International Union for the Scientific Study of Population (IUSSP) held its first world conference in 1927, and the Milbank Memorial Fund had later established the Office of Population Research at Princeton. The United Nations' activities can be seen as the institutional embryo of a global demography, but originally in a highly ambiguous way. Its origin and early fortunes lay less in the material globalization of population processes than in the world superpower status of the post-war United States of America, and the apprehension of its governing class over the geopolitical consequences of population growth in the developing 'third world'. In part via the United Nations, but also through the activities of the Ford and Rockefeller Foundations and the US State Department, global demography became a cold war weapon. The early statistical work of the UN suggested that population growth in the third world was much faster than had been expected (in turn the early data itself proved to be an underestimate). Not only was such global population growth seen as unsustainable, and likely to impede economic, political and social development, but in the context of the cold war it was also seen as likely to create, literally, a breeding ground for the spread of communism. This was the backdrop to the publication of The Population Bomb in which Ehrlich asserted that global overpopulation was about to make Malthus' prediction a reality:' $[t]$ he battle to feed all of humanity is over... In the 1970s the world will undergo famines - hundreds of millions of people are going to starve to death' (1968: xi). The fact that Ehrlich was a biologist rather than a demographer did not stop his views having a substantial impact.

The answer was seen to lie in encouraging family planning and access to cheap contraception with the UN's role shifting from one of data collection and analysis to policy intervention to support family planning programmes under the auspices of the UN Population Fund (UNFPA) established in 1967 with million dollar funding from the United States. As Demeny (2003: 13) notes, from the 1960s to 1980s 'population policy in the developing world became essentially synonymous with family planning programs.' The UN established a series of World Population conferences which became intergovernmental conference from the time of the 1974 
Bucharest meeting as demography became more relevant to states' geopolitical interests.

\section{Demographic transition theory}

The academic paradigm used to analyse demographic change was demographic transition theory. In the first decades of the century demographers on both sides of the Atlantic (Willcox 1916; Carr-Saunders 1922; Thompson 1929; Landry 1934) had all suggested that economic and social modernization was eventually accompanied by a steep decline in both mortality and fertility, with a relatively short period in which fertility falls might lag behind mortality falls, producing a rapid but temporary expansion of population. At the time of its original development this theory attracted little attention (Szreter 1993) since European demographers were more interested in what Glass (1936) called The Struggle for Population: the problem of what was thought (wrongly) to be below-replacement levels of fertility in 1930s Europe and whether modern industrial society and the family were compatible (Davis 1937) ${ }^{2}$. However, in the context of a global cold war, what was originally a theory developed from the studying industrialised countries and framed in terms of demographic consequences that had their origins in social, economic and political change, became recast as a theory of how policies aimed at directly changing demographic behaviour (principally fertility) might, on the contrary, cause desirable social, economic and political consequences in non-industrialised countries (Szreter 1993, Hodgson 1988). Population control was argued to be fundamental to economic development, and informed a great deal of policy and intervention in developing countries. Meanwhile, demographic transition theory became virtually the only analytical framework for academic demography, helped on its way by its formulation in economic terms by the Household Economics of Becker (1991) (Robinson 1997).

This approach eventually suffered two fundamental reverses. At the 1974 Bucharest population conference many third world countries rejected the UN's draft World

\footnotetext{
${ }^{2}$ Replacement level fertility is a term used by demographers to refer to that level of fertility necessary in a population to maintain its current volume in the long term. Frequently this level is stated to be a total fertiltiy rate (see below) of 2.1 children per woman. This is a misnomer however. It applies only in populations where all women survive to the end of their fertile years, and takes no account of falling
} 
Population Plan because of its background assumption that demographic change was more a cause than result of underdevelopment. Alarmed at threats to their state sovereignty implied by a global population initiative and frustrated at any progress on the UN's part in challenging global economic inequality they declared that 'Economic development is the best contraceptive'. At Mexico ten years later, bowing to pressure from the religious right, rather than any recognition of changed development priorities, the US delegation announced, to the astonishment of others, that population growth was a 'neutral phenomenon' in relation to economic development (Finkle and McIntosh 2002). By the time of what was to be the last such conference, in Cairo in 1994, the development perspective of population policy was dropped altogether and the rationale became, instead 'that the programs satisfy important health needs and help people exercise a fundamental human right. ... even though the name of the conference for the first time included a reference to development, scant attention was paid to that concept. Family planning programs were redefined, instead, as reproductive health programs' (Demeny 2003: 15). Five years earlier the fall of the Berlin wall removed much of the original rationale for the United States' strategic interest in demography, rendering the return to dominance of a religious moral conservative discourse much less relevant than it might otherwise have been.

Meanwhile demographic transition theory continued to be a plausible general empirical description of demographic history, but fell apart as a body of work capable of generating testable hypotheses or predicting the future course of demographic trends. In the original model 'the whole process of modernisation' (trade, technological innovation, specialisation, a widening division of labour, the rise of labour and product markets, industrialisation, urbanisation, formal education, growth of scientific and medical knowledge) first lowered mortality, then gave people a new interest in lowering fertility and finally recognition of this interest. 'Natural' fertility control, the virtual absence of any widespread family limitation and 'a surprising lack of knowledge' (Cleland and Wilson 1987: 13) of contraception given almost universal understanding of procreation, was argued to give way to

mortality or of migration, both of which may push the level of replacement fertility well below the 2.1 mark. 
parity-specific, conscious, birth-control ${ }^{3}$. The professional classes were usually the most rapidly affected, but others soon followed. In some versions of the theory this was because industrial capitalism reversed the previously positive material and political impact of having children. However, one of the largest empirical social science research projects ever mounted, the Princeton study on the fall of fertility in Europe, singularly failed to produce evidence consistent with the theory's original postulates and struggled to identify any cross national or regional correlation between the 'whole process of modernisation' and fertility fall (Coale and Watkins 1986). The variety of pre-transition fertility behaviour could hardly be subsumed under a single 'natural' variant. Moving beyond Europe it became clear that although fertility falls were virtually universal by the start of the twenty-first century, they occurred under all kinds of different social, political, economic and even demographic conditions. As Cleland (2001: 62) noted 'in the last 40 years the onset of fertility transition has occurred in settings where infant mortality is 150 per thousand live births and survival at older ages is correspondingly low. In other settings, birth rates have remained unchanged until infant mortality dropped to 50 per thousand.' Conversely, it was far from clear just how effective 'family planning' campaigns in developing countries inspired by diffusion theory had been. However, in a classic example of Kuhn's theory of the evolution of scientific thought (Kuhn 1962) transition theory continued unchallenged as the discipline's paradigm even as the empirical dimensions of its shortcomings became ever more apparent.

Because of this institutional and theoretical background, demography has until recently shown less interest in the theory of globalization than other social sciences, such as economics, political science or sociology, although it has certainly been in the business of producing data about the demographic 'aspects' of globalization. By the latter we understand the progressive integration of the diverse systems that form human relations into one general system (in areas such as politics, finance, history, production, commerce, ideology and so on). However it is perhaps no accident that reliable information about the population of the world has become available, through the efforts of the United Nations, just at the point when, as we argue below, a genuinely global population system has first emerged as a material reality and when

\footnotetext{
${ }^{3}$ Demographers use the rerm 'parity' to refer to the number and order of births. Thus partiy specific control refers to control aimed at producing a specific final desired number of children.
} 
the pace of demographic change has been greater than ever before in human history, and probably greater than it ever will be again.

\section{Population as a reproductive system}

In order to understand population dynamics in global terms, it is first of all necessary to distinguish two quite different uses of the term population: that between population as a stock and as a flow. As a stock, population is an accounting term. A population is simply a group of objects sharing one or more common characteristics at a point in time, including a group of people defined in this way, usually in terms of residence within a territory. With this definition it is possible, at most, to study the exchanges, mixing and displacements between diverse 'stocks', in other words, migration patterns. Included in such movements would be ethnic movements on a grand scale, such as the Germanic invasions of the declining Roman Empire, or the Spanish and Portuguese conquests of the Americas, as well as all manner of other ways in which more or less isolated 'populations' have managed their contact with those beyond their territorial or ethnic boundaries. However this does not bring us any closer to the idea of a global population system and its analysis

As we have argued elsewhere (MacInnes and Pérez 2009a), the key tool of demography is to define populations not as stocks but as flows: as reproductive systems which continue over time, as opposed to their mortal individual human components. This allows us to examine, for example, the 'efficiency' of a population, taking into account the very diverse combinations of existing structural conditions and individual behaviours, and the 'input' (in terms of births and associated reproductive work needed to convert infants into adults themselves capable of carrying on such work), given such conditions, needed to maintain a population over time. If we understand populations as a flow in this way, it also becomes possible to think of globalization in properly demographic terms, and to examine the extent to which the population system itself has become global. We try to do both below, in order to argue that existing diverse population systems are rapidly fusing into one global population system, whose outlines can be sketched. This newly emerging system comprises a quite new mode of reproduction characterised, on the one hand, by an unprecedented and unrepeatable transformation in the system's efficiency (one might even think in terms of the forces of reproduction) and, on the other hand, by 
the transformation of its social relations such that power and decision-making relating to fertility becomes, for the first time, individual and private rather than collective and public. However to understand what follows, a short but necessary methodological argument must be made.

Demography has its own special terminology and as an overwhelmingly quantitative discipline, it own indicators and measurements. Understanding the subtleties of two of these makes a critical appreciation of contemporary population change much more readily accessible to non-demographers. Since population is a flow, and demographic events occur across the life course, a population's characteristics at any point in time cannot fully by grasped by 'period' or transversal measures, since they have no way of distinguishing how far age-dependent variables (which naturally form the essence of demographic analysis) reveal attitudes or behaviour that is rooted in change across successive generations, or cohorts, or changes across the life course within such generations, or some mixture of both. In addition, 'crude' measures, which express demographic events (such as births deaths marriages or divorces) as proportions of or rates within the population for a given time period can be misleading since different populations have very different age structures, and most demographic events are highly dependent on age. For example, a population with a high proportion of young people may have a lower crude death rate compared to another population with a low proportion of young people, even though life expectancy in the former population is much lower, for the simple reason that deaths, by definition, occur at the end of people's lives. When demographic change is rapid, as it surely has been across most of the world over the last century, cohort-based measures, which study the entire reproductive life course of a generation, may give a fuller account of change, but with the grave drawback that they can only be completed in retrospect. In practice 'complete' can be taken to mean women's reproductive behaviour up to the age of forty, since very few women (and surprisingly few men, despite their longer fecundity) become biological parents after this age. However this still means that in the year 2010, we can only have reasonably complete fertility information about women born as early as 1970 . With mortality the problem is clearly greater. We may not know the actual life expectancy of those born in 1970 for another ninety years or so. 
Clearly it is impossible to obtain future knowledge. However it is possible to produce 'synthetic' measures that capture something of the dynamics of population, albeit from a transversal perspective. Two of these are important for our analysis here, the total fertility rate and life expectancy at birth. Crude birth rates depend upon the age structure of a population at a point in time. Other things equal, a population with a high proportion of women in fertile ages (conventionally taken as 15 to 45, or 49) will have a higher crude birth rate. Age-specific fertility rates can be calculated for each year or five-year age group, and these facilitate comparison across populations with different age structures. Making many such comparisons would often be a laborious exercise, so that a total fertility rate (TFR) is calculated which gives the fertility rate that would result were each woman to experience across her lifespan the age-specific fertility rates for all women for that calendar year. This measure is synthetic because it represents what must be a longitudinal process as a transversal one. It inevitably makes assumptions about the 'future' behaviour of younger members of the population in terms of current evidence of the behaviour of older members. This can lead to significant distortions when behaviour is changing over time. Such distortions are inevitable: we cannot know the future. However we can be aware of these distortions and do our best to interpret such synthetic evidence in the light of what we know about change. A second, and easily overlooked, limitation of the TFR is that it takes no account of mortality. This becomes important when we consider population trends over time and population replacement. Other things equal, a population with substantial early mortality will need a much higher TFR to reproduce itself. This is because many births will be partly or wholly 'wasted' from the perspective of reproducing the population if female children die before reaching the end of their fertile years. Moreover, a population with higher mortality will need a correspondingly higher fertility rate to maintain a given volume of population. In fact this will vary directly with mean life expectancy. If people live twice as long, the same fertility rate will deliver twice the volume of population (Henry 1965).

Life expectancy at birth $\left(e_{0}\right)$ is a similar synthetic measure calculating the mean years of life that would be achieved by someone born in a population today who experienced the age-specific mortality rates prevailing today in that population across their life course. Life expectancy clearly suffers the same drawback as total fertility. We might expect that the trend reduction in mortality rates will continue (although it would be 
foolish to discount the possibility of some new epidemiological challenge) in which case the actual life expectancy of those born today will almost certainly be significantly higher. Again this arises because we only know the real life expectancy of the already dead, and predominantly older, members of the population at the current point in time. However, life expectancy at birth has one further shortcoming for the unwary. It is an average measure but one that is often highly skewed and has a wide dispersion, particularly in countries with low life expectancies. This is because for many populations the risk of death may actually be highest in the earliest years of life. In most of the world until the second half of this century up to one quarter or more of infants born died before their first birthday. Famines or epidemics might double this number for short periods. Such mortality reduces life expectancy dramatically, so that for most of human history it has probably been around 25 to 30 for most populations most of the time. However this does not mean that most people died at thirty. It means rather that their chances of survival to older ages were modest. A quarter might be dead before reaching five years of age, further similar proportions by their fifteenth and fiftieth birthdays, while a lucky few might live on into their eighties or nineties.

\section{The prehistory of population}

In history it is usually misleading to refer in general terms to 'the past', as if it were some coagulated, unchanging mass. However, in demography it has rather more justification than usual because the magnitude and speed of recent change is indeed not only unprecedented but also logically impossible to repeat. What dominated the past was premature death. If populations comprise human groups with both continuity over time and their own diverse ways of achieving such continuity, such diversity was almost universally rigidly conditioned until the eighteenth century (and for many areas of the world until much more recently) by low life expectancy and the very high risk of an early death. In what Omran (1971: 512) called 'the age of pestilence and famine ... life expectancy was short and human misery was assured'. Data is scanty and requires painstaking effort to reconstruct, but it appears that crude mortality rates oscillated erratically with epidemics, famine or warfare between a range of around 20 to 50 per 1,000 (but with occasional much higher peaks) while mean life expectancy at birth ranged from around twenty to the low 
thirties (Omran 1971; Coale 1986; Livi Bacci 2001; Riley 2001). A poor harvest, adverse weather, warfare, brigandage or epidemics easily severed what was always a tenuous hold on life for most ordinary people and intermittently sent mortality rates heavenward. Less than a half of most female populations might expect to live through their entire reproductive years if we define these as ending at 45 . Such factors did not directly impose the details of whatever survival strategy a population might choose, but they did impose the need to control fertility, subject to two conflicting pressures. Fertility had to be kept high enough to balance the ravages of a high and volatile mortality rate, but too high a rate of fertility might, if it led to too many mouths to feed, drive mortality up on its own account.

Within this stage we can find many quite distinct demographic systems, each of which tried to maintain such fertility as was necessary to secure the reproduction of population in the long run, along with checks to avoid fertility levels that might expand the population beyond a level that available resources and technology could support. In many parts of Asia the early and widespread marriage of women was combined with infanticide in adverse times (Lee and Feng1999). In Western Europe (Hajnal 1965) it was marriage that was controlled, rather than fertility within it, with marriage ages increasing, and fertility rates decreasing, when times were hard. Indeed Laslett (2000) suggests that England's demographic system not only vanquished famine as a significant contributor to mortality as early as the sixteenth century, but can plausibly be seen as an important precondition of the world's first industrial revolution.

Elites more concerned with their descendents' inheritance of their wealth and power sometimes practiced fertility control (Henry 1956). To their (somewhat) better survival rates and life expectancy was added the concern to avoid 'diluting' their estate, offset by their need to secure an heir. Both social elites, and particular territorial areas (such as governing cities) had mechanisms to 'adopt' the produce of other populations to the goal of their own survival. However, logically, these were not strategies that could be extended to the entire population so that even in Western Europe the norm was levels of fertility far above our current experience, with completed fertilities (that is the mean number of children a cohort of women would have in their lifetimes) no lower than four (Laslett's minimum estimate for England) and often nearer five or six. Since averages take no account of the significant 
proportion of women who never married, and include women dieing before reaching the end of their reproductive years, this translated everywhere into very large family sizes. Laslett reports 21 births as the maximum encountered for any one woman in the historical reconstruction of English demography. The diverse demographic systems in operation had one common feature, namely the intense regulation of the means of reproduction, women's bodies, principally through the institutions of church and state, the norms surrounding sexual activity and sex roles, illegitimacy, marriage, family and kinship obligations and property law. Patriarchy might have taken many forms, but we have no good empirical evidence of any hitherto existing society without it.

\section{The Decline of Mortality}

From around the middle of the eighteenth century, although possibly earlier in England, mortality was slowly conquered by improvements in nutrition, medical knowledge, public health, sanitation and economic progress. Figure 1 shows just how gradual this change was, using the data for Sweden that allows us to track changes in cohort life expectancy at birth (rather than its more widely available period equivalent) from an unusually early date. Note how progress in the struggle against mortality is fitful until the final quarter of the nineteenth century, however by the end of that century victory is well established, such that mean life expectancy reached 70 for those born in 1916. 
Figure 1 Life expectancy by birth cohort, Sweden 1751-1916.

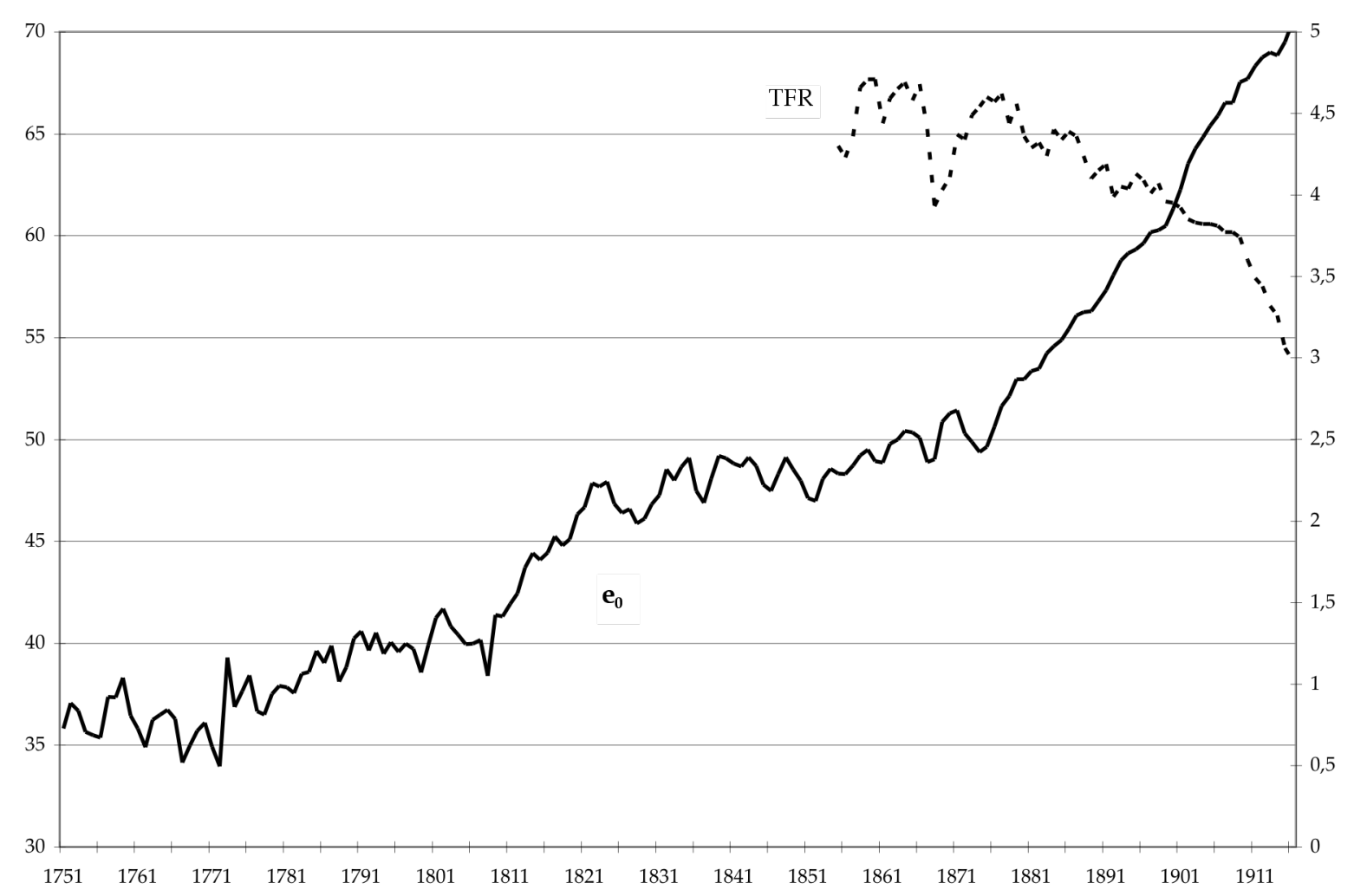

Source: Human Mortality Database. University of California, Berkeley (USA), and Max Planck Institute for Demographic Research (Germany). Available at www.mortality.org or www.humanmortality.de (data downloaded on Jan 04 2009);

As we have seen, demography eventually came to understand this fall as part of the demographic transition, but the initial reaction to falling mortality and fertility was more often the fear that low fertility might lead to a stationary or even declining population (Teitelbaum and Winter 1985). It was in this context that eugenicist alarms were sounded about the prospect of 'race suicide' driven by 'neo-Malthusian' family limitation by within the 'fittest' (i.e. wealthiest) strata of the population. Feminism came in for particular criticism, being blamed for diverting women from their naturally determined and inexorable maternal vocation and threatening 'sex extinction' (Kenealy 1920). One exception to this reaction was the work of Alva Myrdal, who almost alone amongst early theorists of demographic change argued in Nation and Family (1939) that greater gender equality and the collectivisation of the costs of rearing children through fiscal transfers and public provision of services would sustain fertility. Myrdal's work can be seen as the intellectual genesis of what was to become the Scandinavian welfare state. This current in demographic thought 
weakened with the post-war baby boom (which actually had its origins in the 1930s) and, as we have seen above, once the focus became the populations of the developing world, the demographic transition model, originally developed to explain the experience of North-west Europe, was now used to make the case that high, not low fertility was the problem. However it never disappeared entirely, continuing to underpin French demography's fusion of nationalism and natalism as exemplified in the work of Sauvy (1959) or Dumont (2008) and subject to withering criticism by Le Bras $(1991 ; 1998)$, so that when fertility rates resumed their downward trend in Europe in the 1970s and 1980s, it promptly re-emerged (MacInnes and Pérez 2007).

\section{The rise of mass maturity}

The development of the world's population over the last half century can perhaps best be illustrated with a single fact. By 2000, the majority of those who had comprised the world's population in 1950 were dead. Fifty years from now, however, most of those alive today will still be around, despite the fact that the average age of the world's inhabitants is now higher than it was in 1950 (a median of 29 years compared to 24). This is because the biggest social change of the 20th century was the defeat, across almost all of the world, and for the first time in human history, of premature death. In 1950, seven out of ten of the world's women lived in countries with female life expectancy at birth under 65 years. Life expectancy was well below this threshold throughout Africa and Asia, where it was generally in the low 40s, and Latin America and the Caribbean, in the low 50s. Only in Europe, North America, Australia and New Zealand, Israel, Cyprus, Armenia, and by a whisker, Japan, could women expect to reach old age, thus defined. Even within Europe most of the Balkans, Romania, Spain and Portugal still fell below this threshold. Country averages conceal differences by region, class or ethnicity within states so that although White women in the US comfortably exceeded the threshold in 1950, black or African American women did not pass it for almost another ten years. By the first decade of the new millenium however, except in sub-Saharan Africa, and a handful of countries beyond (Bangladesh, Haiti, Cambodia, Laos, Ethiopia and Eritrea), women could be confident of reaching their $65^{\text {th }}$ birthday.

What became evident as the twentieth century progressed was that mortality declines which had developed over some centuries in Europe, were achieved much 
more rapidly in developing countries, thanks to their ability to take advantage of improvements in medical knowledge, especially in combating infectious diseases, and recognition of the importance of public health and education, as well the impact of rising nutrition levels and living standards provided by economic development (Riley 2001). Figure 2 shows the fall in infant mortality in Sweden, Spain, Chile and Egypt. An achievement that had taken well over a century in Sweden was achieved by Spain in half that time and by developing countries elsewhere still more rapidly.

Table 1 compares the under five mortality rates (the number of children per 1,000 live births who die before their fifth birthday) in 1970 and 2005 for a range of countries, as well as the percentage of each cohort born around 2005 that would reach their $40^{\text {th }}$ birthday given current mortality rates. As recently as 1970 these mortality rates were often up to ten times those of affluent countries. However by the start of the new millennium, most developing countries had largely closed this gap, and many had overtaken the Russian Federation in terms of life expectancy. The exceptions were to be found mostly in sub-Saharan Africa. 
Table 1 Under 5 mortality and probability of reaching age 40, 1970 \& 2005

\begin{tabular}{lrrr}
\hline Country & \multicolumn{2}{l}{ Under 5 mortality \%o } & $\begin{array}{r}\text { Survival to age } \\
\text { nn (2005) }\end{array}$ \\
\cline { 2 - 3 } & 1970 & 2005 & \\
US & 26 & 7 & 96.5 \\
Russian Federation & 36 & 18 & 89.3 \\
China & 120 & 27 & 93.2 \\
Turkey & 201 & 29 & 93.5 \\
Brazil & 135 & 33 & 90.8 \\
Egypt & 235 & 33 & 92.5 \\
Iran & 191 & 36 & 92.2 \\
Bangladesh & 239 & 73 & 83.6 \\
India & 202 & 74 & 83.2 \\
Pakistan & 181 & 99 & 84.6 \\
Myanmar & 179 & 105 & 79.0 \\
Ethiopia & 239 & 164 & 67.7 \\
Nigeria & 265 & 194 & 61.0 \\
Dem. Rep. of the Congo & 245 & 205 & 58.9 \\
\hline
\end{tabular}

Figure 2 Infant Mortality (\%o): Sweden, Spain Chile and Egypt 1801-2005

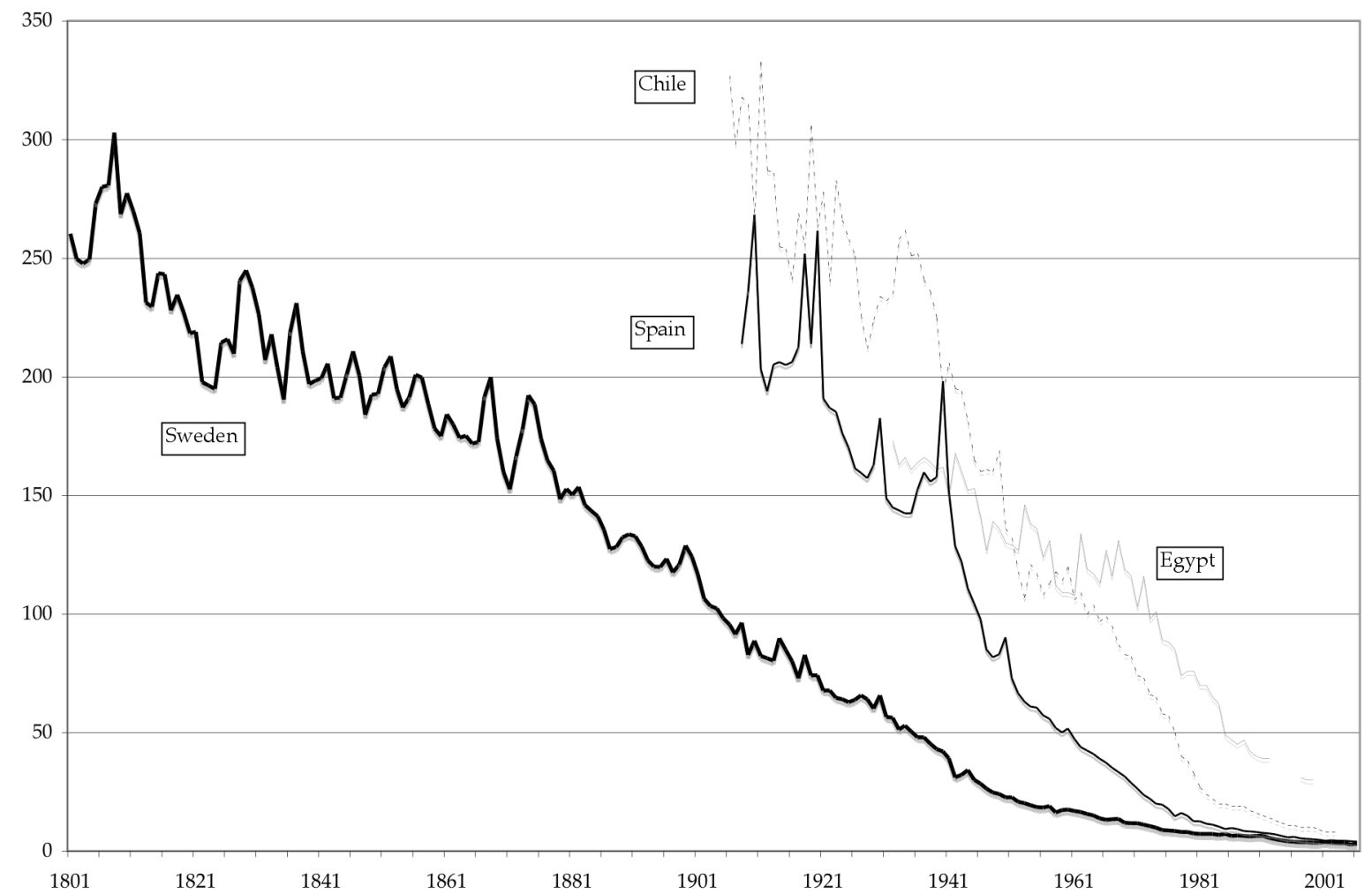

Sources: Human Mortality Database. University of California, Berkeley (USA), and Max Planck Institute for Demographic Research (Germany). Available at www.mortality.org or www.humanmortality.de (data downloaded on June 24 2008); Chesnais (1986: Annexe 5.3); Child Mortality since the 1960s: A Database for Developing Countries, United Nations Department of Economic 
and Social Development, NY: 1962; Anuario De Estadísticas Vitales 2005, Santiago de Chile: Instituto Nacional d'Estadistica.

Such mortality falls were usually followed rapidly by corresponding falls in fertility, resulting in the great rise in the efficiency of global population reproduction. At first, and for a relatively short period, the result of this improvement was the rapid expansion of the global population which expanded faster in absolute terms than it had ever done before, and, in all likelihood, will ever do again, rising from around two and a half billion in 1950 to around 6.7 billion in 2009. This expansion is now coming to an end, although population momentum will probably carry the global population above 9 million by the middle of this century. However the more enduring effect has been the fall in the proportion of social effort devoted to fertility, through the greatly reduced volume of births needed to sustain a population. This fundamental shift has precipitated an even greater social revolution, which is spreading around the planet: the rise of personal autonomy in fertility decisionmaking, the consequent erosion of patriarchy (to the point of collapse in much of the North) and the rise of gender quality (MacInnes and Pérez 2009b).

Figure 3 shows the general outline of this process for the world as a whole. The annual volume of births, which in 1950 stood at just under 100 million, grew by around one third by 2005. The volume of population more than doubled however, from 2.5 to 6.7 billion, as these births have given rise to longer lives. The increase in the volume of births stayed modest even though the global population of women of fertile age almost trebled, because fertility rates fell rapidly. 


\section{Figure 3 World births and population 1950-2005}

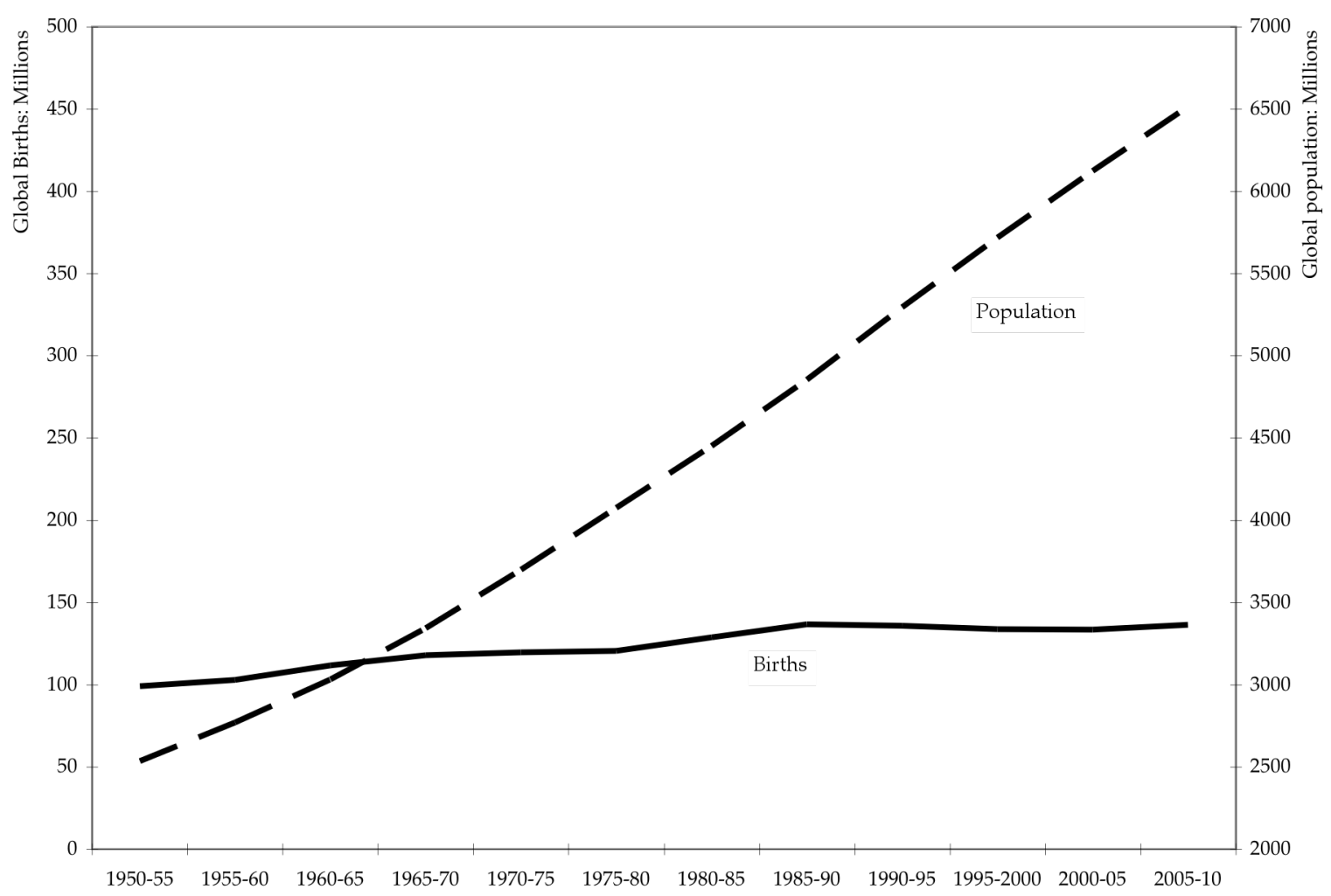

Figure 4 shows the details of this process for the world, divided into three major regions: the more developed countries, less developed, and the least developed. ${ }^{4}$ It plots the fertility (TFR) for each of these areas against life expectancy at birth $\left(\mathrm{e}_{0}\right)$ for each five-year period from 1950 to 2005, representing each area in proportion to its population in each period. The figure illustrates four aspects of change across this half century. First, rises in life expectancy quickly became associated with falls in fertility: the circles move rapidly leftwards within a few years of shifting upwards. Second, change has been greatest in the less developed countries, which have

\footnotetext{
${ }^{4}$ We use the United Nations definitions: the more developed countires comprise all of Europe and Northern America, Australia, New Zealand and Japan. The less developed regions comprise all regions of Africa, Asia (excluding Japan), Latin America and the Caribbean, Melanesia, Micronesia and Polynesia, excluding the least developed countries as defined by the United Nations General Assembly in December 2003: Afghanistan, Angola, Bangladesh, Benin, Bhutan, Burkina Faso, Burundi, Cambodia, Cape Verde, Central African Republic, Chad, Comoros, Democratic Republic of Timor-Leste, Democratic Republic of the Congo, Djibouti, Equatorial Guinea, Eritrea, Ethiopia, Gambia, Guinea, Guinea-Bissau, Haiti, Kiribati, Lao People's Democratic Republic, Lesotho, Liberia, Madagascar, Malawi, Maldives, Mali, Mauritania, Mozambique, Myanmar, Nepal, Niger, Rwanda, Samoa, Sao Tome and Principe, Senegal,Sierra Leone, Solomon Islands, Somalia, Sudan, Togo, Tuvalu, Uganda, the United Republic of Tanzania, Vanuatu, Yemen and Zambia.
} 
achieved levels of fertility and life expectancy previously reached only by industrialised states. Third, progress in the least developed countries stalled after the 1970s: fertility continued to fall, but gains in life expectancy halted. Finally, the dramatic convergence between the more and less developed countries means that for the first time we can analyse a truly global population system.

Figure 4 Life expectancy at birth, fertility and population size at five year intervals for more, less and least developed countries, 1950 - 2005.

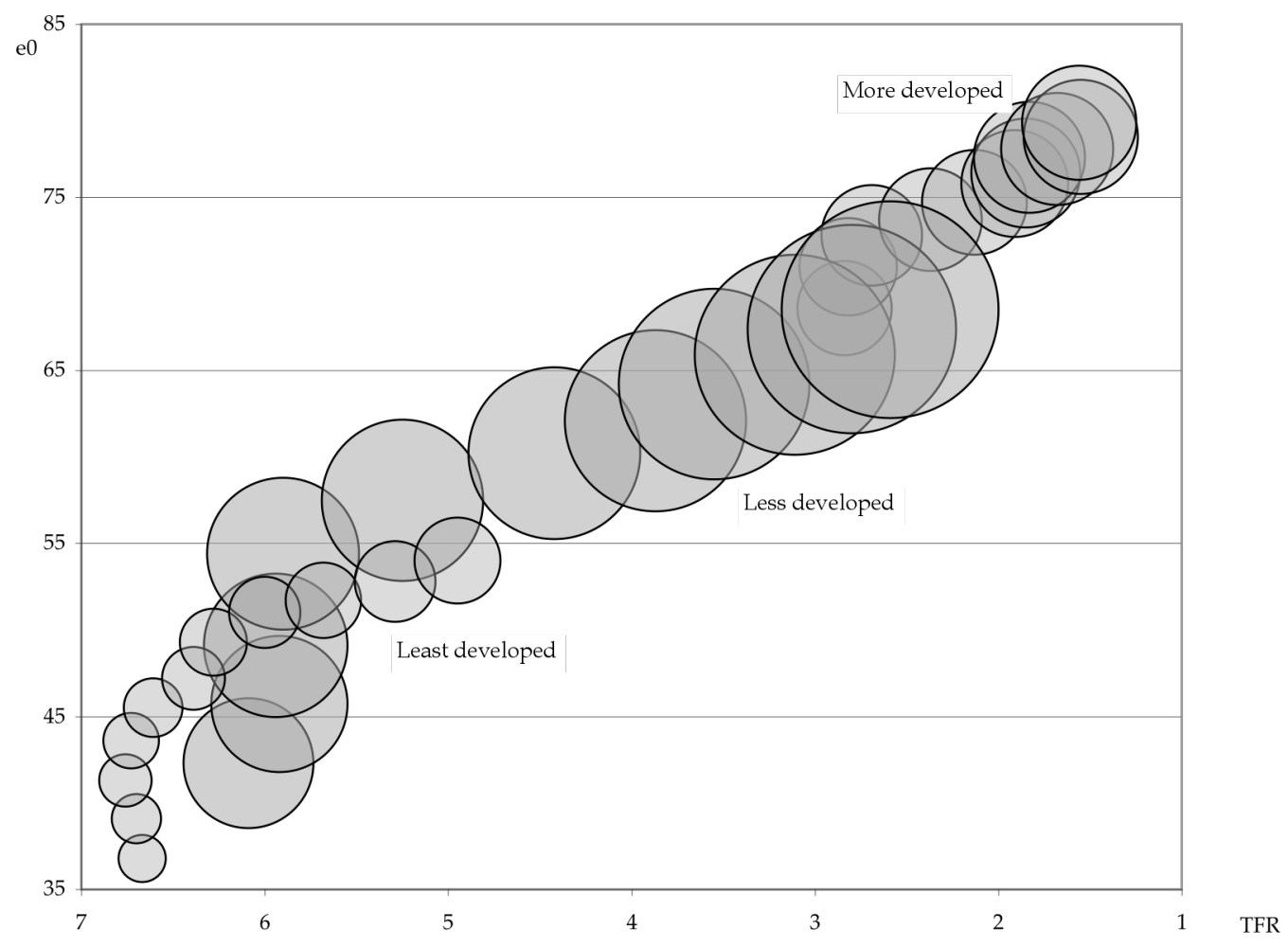

Of course, the emergence of a global population system has taken place in a world structured by great inequalities of material affluence. The relationship between fertility, life expectancy and the standard of living as measured by individual or state-wide income or wealth has been a favourite and controversial field of investigation, above all by economists.(e.g. Lee 1981, Schultz 1985, Becker 1991). Without entering into the detail of the debate, we can note two points relevant to our argument here. It is clear that the reproductive revolution can begin even with a modest level of development. Many countries with levels of GDP well below that of the richest countries nevertheless manage to approach their life expectancy rates, chiefly by reducing murderous levels of infant mortality. However, 
underdevelopment, especially when compounded by political disorder, civil and ethnic warfare and the effect of HIV, can also reverse progression on mortality: the experience of much of sub-Saharan Africa. Second, economic development itself does not erase inequalities in life expectancy, either between states or within them. In most less developed countries, infant mortality rates for the poorest quintile of the population are two to four times higher than for the richest quintile. A recent study in Scotland examining the spatial distribution of mortality found an inner city area of Glasgow, characterised by poverty, unemployment and drug abuse, where male life expectancy was 54: the level for some of the world's poorest countries. In an affluent suburb nearby it was no less than thirty years higher.

Around 2008 about ten per cent of the world's people lived in states where GDP per capita was 1,500\$ or less. Conversely their counterparts in Europe and North America lived in states with economies that were over twenty times richer, and as we shall see below, this disparity maps directly onto wages and living standards. It is Perhaps it is because of the magnitude of this difference, one that makes it hard to think in global terms when the everyday conditions of life vary so much across areas of the world, that less notice than one might have expected has been taken not only of demographic progress, in the sense of longer, healthier lives, but of demographic convergence, in the sense of the patterns of population reproduction and the particular form the latter have taken. Demographic progress has also been overlooked because one large area of the world has not only missed out on it but has been deteriorating. Life expectancy in parts of sub Saharan Africa has been falling and fertility falls there have mostly stalled (Bongaarts 2008). Finally the fragile state of theory within demography as a discipline, dominated by the demographic transition paradigm, has often obscured the wider significance of such convergence .

The last half century of world population history has been about the rise in cohort life expectancy: the inexorable increase in the proportions of successive generations reaching older age points. Although the precise mechanisms of the linkage may be heterogeneous, wherever they have take place such improvements have been associated with the rapid arrival not just of lower fertility but fertility levels previously only ever experienced in affluent countries before and after the baby boom, in the 1930s, and since the 1960s. The world is very rapidly becoming one in which most women who do have children will have only one or two. The result of 
this is what has come to be known as 'population ageing': an increase in each country in the proportion of older cohorts and corresponding decrease in the proportion of younger cohorts. Its precise from and impact varies a good deal across countries, but it is a thoroughly global phenomenon. In affluent societies it has usually been seen as a challenging or threatening development. On the contrary, we argue below that this democratisation of longevity, for that is what it is, has been the twentieth century's greatest achievement.

\section{The decline of fertility}

In the early 1950s, if we looked beyond Europe, North America, Australasia and Japan, just a handful of countries, accounting for less that $2 \%$ of the world's population, had total fertility rates under five. The only states of any size with fertility levels below this were Argentina (at 3.2) and North Korea (3.4). In the rest of the world, accounting for over three fifths of its population, the fertility rate was over six. In countries as diverse as Mexico, Turkey, Algeria, Nigeria, Ethiopia, Iran or the Philippines, it was around seven. It must be borne in mind that fertility rates of this magnitude, given the proportion of women who never married, were infertile or who died before reaching the end of their fertile years, implied a much greater numbers of births for most mothers. This was especially so because beyond the industrialised states, life expectancy at birth was almost universally low: around 40 for both Asia and Africa, and a little over ten years more in Latin America and the Caribbean (Table 2).

Fifty years later, less than the span of a couple of generations, we find a picture that is utterly transformed for all but that tenth of the world's population condemned to live in sub-Saharan Africa. Elsewhere, only four countries in the world now have a fertility rate above five: Afghanistan, Yemen, Oman and the Occupied Territory of the Gaza strip. Half the world's population now live in countries with fertility rates near or below what demographers sometimes refer to as 'replacement level' (roughly speaking the fertility level needed to replace the current population, assuming that no women die before reaching the end of their reproductive years). Among the countries with 'below replacement fertility' are not only such well know cases as China, Singapore or South Korea, but less publicised examples such as Algeria, Iran, Viet Nam, Sri Lanka, Myanmar, Thailand or Turkey. Indeed, as Figure 6 suggests, 
despite the publicity its 'one child' policy has received, the fertility drop in China has been no greater than that in many other rapidly developing countries. Fertility rates pay little attention to either the ideology of the regime in power or religion. The United States now has a higher fertility rate than either Viet Nam, governed by the Vietnamese Communist Party, or Iran, officially a Shia Muslim Theocracy.

While world fertility has almost halved since 1950, life expectancy at birth has increased by one half, rising at around five years per decade. Fifty years ago, in most of the world, around one in six or one in seven babies died before their first birthday. Today in sub-Saharan Africa almost one in twelve still die. Elsewhere, almost half the world's people live in countries where infant mortality is 25 per thousand or below: rates similar to those of the United States or the UK in the early 1960 s.

Table 2 Fertility, life expectancy at birth and infant mortality by major world region $1950-5$ and $2000-5$

\begin{tabular}{|c|c|c|c|c|c|c|}
\hline & $1950-5$ & & & $200-5$ & & \\
\hline & $\begin{array}{l}\text { Fertility } \\
\text { rate (TFR) }\end{array}$ & $\begin{array}{l}\text { Life } \\
\text { expectancy at } \\
\text { birth }\left(\mathrm{e}_{0}\right) \\
\text { (both sexes) }\end{array}$ & $\begin{array}{l}\text { Infant } \\
\text { mortality } \\
(\% o)\end{array}$ & $\begin{array}{l}\text { Fertility } \\
\text { rate (TFR) }\end{array}$ & $\begin{array}{l}\text { Life } \\
\text { expectancy at } \\
\text { birth }\left(\mathrm{e}_{0}\right) \\
\text { (both sexes) }\end{array}$ & $\begin{array}{l}\text { Infant } \\
\text { mortality } \\
(\% o)\end{array}$ \\
\hline N Africa & 6.9 & 41.8 & 189 & 2.9 & 68.2 & 41 \\
\hline $\begin{array}{l}\text { Sub-Saharan } \\
\text { Africa }\end{array}$ & 6.8 & 37.6 & 177 & 5.2 & 51.0 & 80 \\
\hline Asia & 5.9 & 41.0 & 176 & 2.4 & 70.8 & 30 \\
\hline Europe & 2.7 & 65.6 & 72 & 1.5 & 75.2 & 7 \\
\hline $\begin{array}{c}\text { Latin America } \\
\text { \& Caribbean }\end{array}$ & 5.9 & 51.4 & & 2.4 & 73.1 & 22 \\
\hline N. America & 3.5 & 72.0 & 29 & 2.0 & 78.4 & 6 \\
\hline Oceania & 3.7 & 66.7 & 61 & 2.3 & 77.8 & 13 \\
\hline World & 5.1 & 46.4 & 153 & 2.6 & 69.5 & 32 \\
\hline
\end{tabular}

Source: 1950-55: Population Division of the Department of Economic and Social Affairs of the United Nations Secretariat, World Population Prospects: The 2006 Revision and World Urbanization Prospects: The 2005 Revision, http://esa.un.org/unpp, January 4, 2009; 2008: Central Intelligence Agency The 2008 World Factbook, https://www.cia.gov/library/publications/the-world-factbook/index.html, January 4, 2009.

Figure 5 shows the very high relationship between fertility and life expectancy for the largest 25 countries in the world, which account for about three quarters of world population, comparing their position in 1950 and now. The light grey circles represent countries around 2005, and the black ones those same countries around 
1950-55. It can be seen that fifty years ago two quite distinct demographic regimes existed. A few countries - the USA, UK, France Germany, Italy, Japan Russia and the Ukraine, represented by the cluster of eight black circles at the top right hand side of the graph, enjoyed relatively long life expectancies and had lower fertility rates than countries elsewhere. All the other largest countries were clustered at the lower left hand side of the graph with high mortality and correspondingly high fertility. Fifty years on, and it can readily be seen that with a few exceptions, the cluster from the bottom left of the graph has joined those at the top right, although the latter have continued to develop still lower rates of fertility and longer life expectancies.

There is also a remarkable absence of countries from the middle of the graph. We find this effect too if we repeat the graph for all countries. This is because when fertility and mortality fall they neither drift down gradually nor do they appear to arrive at other end points, although, as the experience of sub-Saharan Africa shows, such development is not automatic. It is here we find virtually the only countries where the shift to a new demographic regime has 'stalled' (Bongaarts 2008).

Figure 5 Total Fertility and Life expectancy at birth , 1950-5 and 2000-5

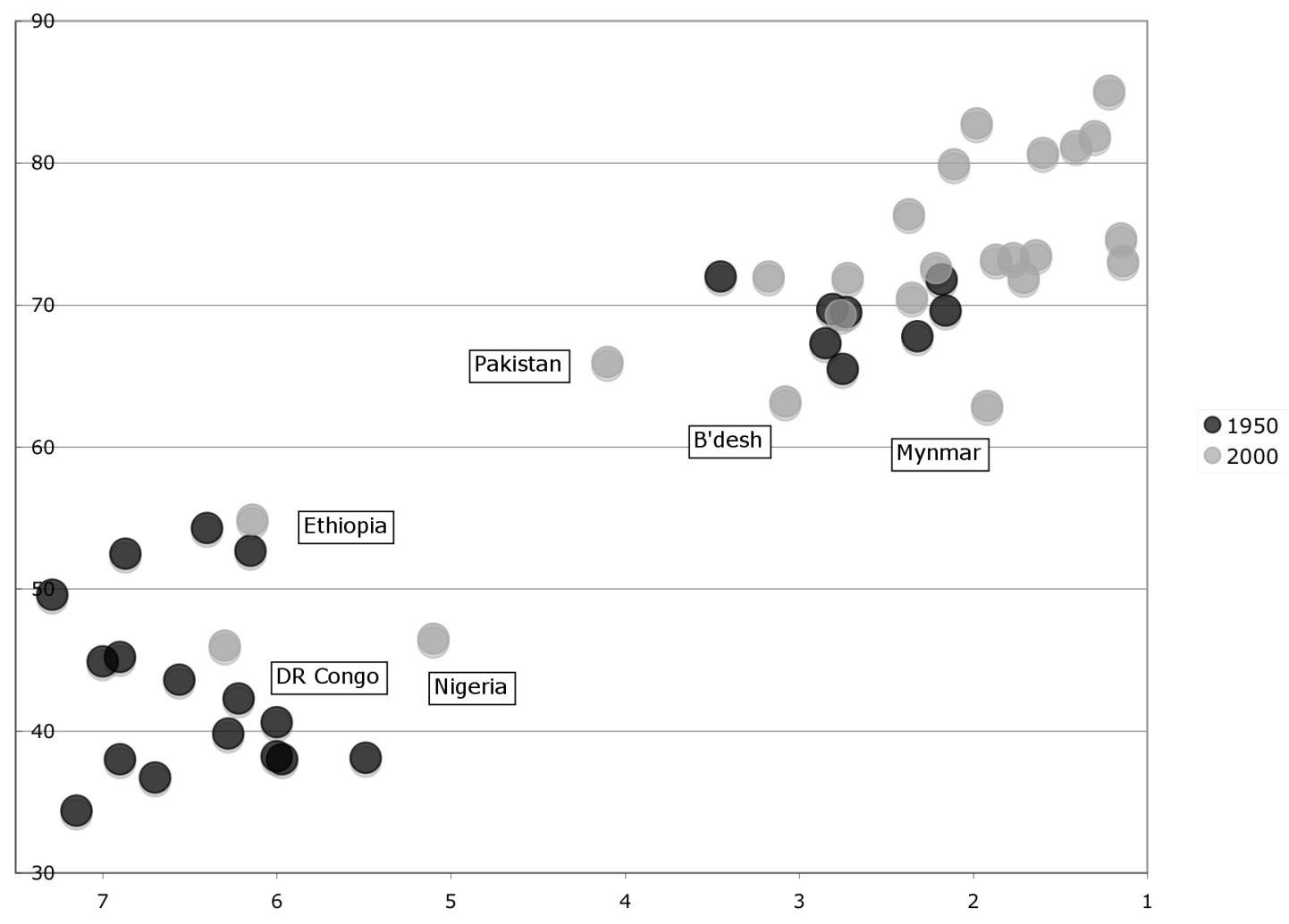


Figure 6 shows the process in rather more detail for the eight largest countries of the world (which account for just over half its population). In addition to the data contained in figure 2 countries are depicted proportional to the size of their population in each of the two time periods, and current GDP per capita (in US\$ ppp) and infant mortality rates (per 1,000 live births) are shown for the later period.

Figure 6 Total Fertility, Life expectancy at birth , GDP and infant mortality 1950-5 and 2000-5.

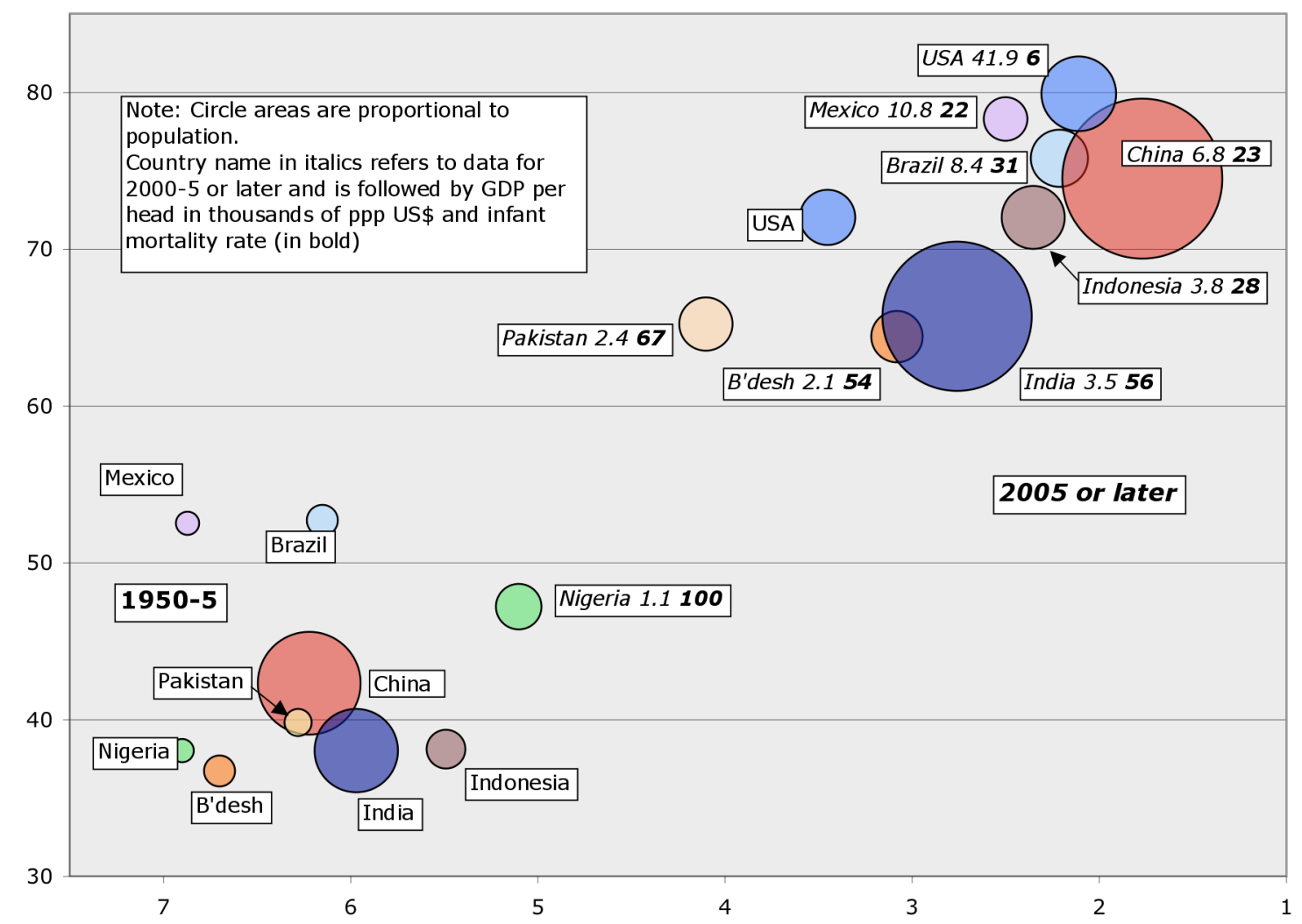

\section{Migration}

The development of a global demographic regime has also changed migration. It has often been assumed that globalisation has caused unprecedented spatial mobility (e.g. Urry 2000), especially across national frontiers, but as we shall see, states' determination to police such mobility has kept migration below the levels reached before the First World War. Almost the entire cost of this is borne by the world's poor. Indeed, states spend about one third as much on maintaining migration controls as they do on all development aid (Pritchett 2006) It is often forgotten that 
the world's most powerful state was not only founded by migrants, but continues to derive its demographic momentum from them. It was only at the beginning of the twentieth century that most states either developed much interest in controlling migration across their frontiers, or the means to do so (Torpey 1999). Indeed whether they ever have or ever will be able to do so effectively is doubtful. Despite spending billions of dollars attempting to control its border with Mexico, using unmanned drones, seismic sensors, and some 36,000 border guards (Economist 3 January 2008) more than half a million migrants are estimated to enter the US unlawfully each year, on top of the million who enter as official permanent residents, and a third of a million granted temporary entry. Some do not make it. 453 people died attempting to cross this border in 2005: about twice the number of those killed trying to cross the Berlin Wall in its 27 year history. The US thus dominates contemporary global migration.

Emigration to the colonies was not only substantial from the seventeenth century onwards, it was associated with the mass destruction and genocide of indigenous peoples in North and South America, the Caribbean, Australia and elsewhere. An estimated 15 million slaves were taken to the Americas by 1850 (when world where population was less than one quarter of today's total). Potts (1990) estimates that up to 37 million indentured labourers were used in the nineteenth and early twentieth centuries in systems analogous to slavery. Around 55 million Europeans emigrated to the colonies between 1850 and 1914 mostly to the United States. This 'raised the New World labour force by a third, and decreased the Old World labour force by an eighth' (Hatton and Williamson 1998: 4). Industrialisation also drove international migration within Europe, of Irish and Jews to Britain, of Poles, Italians, Belgians and Dutch to Germany, and of many different countries to France. Polanyi (1944) argues that the free movement of labour was one of the key elements of the capitalist order that fell apart after World War 1.

It is often forgotten that the world's 'huddled masses' who emigrated to the United States, both then and now, did so not only because of political exile or economic oppression, important though these were, but also because of economic opportunity. Hatton and Williamson (1998:35) estimate wages in the receiving countries in the 1870s at 50 per cent higher than those prevailing in Great Britain, around double 
those in Germany, and between two and three times those in Ireland, Norway, Sweden and Italy.

Just as states responded to the economic depression of the interwar period with protectionist policies, they began to restrict immigration. The United States started to regulate immigration from the 1880s onwards, on racial grounds, first barring Chinese and Asians, and under the influence of eugenic ideas, Southern Europeans and Latin Americans in 1920 (Mosisa 2002). An exception to the general picture was France, where the vast loss of men in the Great War, combined with a long established low fertility rate, led to the inflow of some two million immigrants in the 1920s, many of whom were promptly sacked and deported as the 1930s depression took hold (Castles and Miller 2003).

The long global capitalist boom that followed from the end of the Second World War to the oil shock of the 1970s also stimulated migration, such as the that from the Commonwealth countries to the UK, or the 'guestworker' system in Germany that drew in some two million Turks. By the end of the boom between six and eight per cent of the populations of most European countries comprised foreign born immigrants. While immigration to the United States did not feature in the long boom (instead this was characterised by the mass migration of blacks from the southern states) the reform of its immigration legislation in 1965 led to a steady increase in immigration till it reached its current volume.

By 2005 the UN estimated that 190 million people were international migrants, almost 3\% of the world's population, rather more than double the volume of thirty years ago. Of these some 13 million were refuges. However accurate data on migration in general and refugees in particular are difficult to collect since much immigration is clandestine, in some countries the status of refugees is contested, and in the poorer countries of sub-Saharan Africa, ravaged by civil and ethnic warfare, estimates of the numbers involved is a question of enlightened guesswork. International migration today is dominated by flows of people towards richer economies in search of work, whether in formal or informal employment, that is usually precarious, badly paid or with poor or unsafe conditions of work that make it unattractive to the resident established population. However many migrants are relatively highly skilled: a World Bank survey 2000 of OECD economies estimated that over one third have college educations. The single country with the largest 
migrant stock is the United States, with 38 million migrants, $13 \%$ of its population. Europe, excluding the former Soviet bloc countries, has some 42 millions while the Russian Federation, Ukraine and Belarus have about half that number, although here many 'migrants' are people who have become so as a result of changes in borders and citizenship definitions, rather than by any movement of population. The rich Gulf states of Saudi Arabia, Bahrain, Kuwait, Oman, Qatar and the Emirates hold another 13 million migrants, accounting for over one third of their populations. One investigation found construction workers in Dubai earning 400-500 dirhams a month (90-110\$) for working 60 hours a week or more. Housed in labour camps they had no access to healthcare or civil or political rights, such as the right to form unions, while the employment agency held their passports (Guardian, 8 October 2008). For illegal workers without papers, conditions were much worse.

Singapore and Hong Hong hold 5 million migrants, just over two-fifths of their population, while Australia and New Zealand account for another 5 million migrants, around one fifth of their populations. However not all richer countries depend on migration. Japan has only 2 million migrants, less than $2 \%$ of its population. The proportion in South Korea, and Thailand is similar, whereas Viet Nam claims to have just twenty thousand migrants in a population of 84 million.

However, although these volumes of migration at first sight appear to be high, they are well below the levels of movement across the Atlantic in the forty years before 1914, despite the fact that several forces encouraging migration have become much stronger since then (Pritchett 2006). Technological change has revolutionised both travel and communications not only making migration cheaper, faster, safer and easier but also by facilitating that social support networks that are often vital to it. Economic and cultural globalisation, sustained by new communications technology such as satellite broadcasting and the web, together with the end of the cold war and increased fluidity in geopolitics, has probably reduced the cultural and symbolic distance between people in different parts of the world. Increases in absolute standards of living almost everywhere beyond sub-Saharan Africa, together with the great increase in urbanisation, mean that more of the world's poor than ever before have the minimum resources necessary to put the desire to migrate into practice. There is now, for probably the first time in history a genuinely global proletariat, whose size is growing rapidly. Finally, and most importantly, income differentials 
between rich and poor countries are far higher than those between the old and new worlds at the end of the nineteenth century. The last two points deserve more detailed attention.

As Table 3 shows, since 1980, the global workforce has increased by more than half, from 1.9 to 3.1 billion, and almost all of that increase has been in the less developed countries, and associated with urbanisation, as shown in Table 4. However this comparison understates the degree of change, since until around the fall of the Berlin Wall, much of the economic activity in the Soviet bloc, India and China was only very weakly integrated into the global capitalist market. Freeman (2005) thus suggests that the gobal proletariat probably doubled in size during the 1980s and 1990s, and most importantly, brought a vast army of increasingly well-qualified workers paid a fraction of the wages typical of older industrialised countries into the global marketplace.

Table 3 Economically Active Population (15+) 1980 - 2006 (millions)

\begin{tabular}{lrrrr}
\hline & 2006 & 1980 & Increase & $\%$ Increase \\
\hline More developed countries & $\mathbf{6 0 8}$ & $\mathbf{5 1 6}$ & $\mathbf{9 2}$ & $\mathbf{1 8}$ \\
Less developed countries & $\mathbf{2 4 7 7}$ & $\mathbf{1 3 8 7}$ & $\mathbf{1 0 9 1}$ & $\mathbf{7 9}$ \\
$\quad$ of which & & & & \\
Africa & 366 & 172 & 194 & 113 \\
Asia & 1912 & 1142 & 769 & 67 \\
Latin America \& the Caribbean & 263 & 126 & 136 & 108 \\
World & $\mathbf{3 0 8 5}$ & $\mathbf{1 9 0 3}$ & $\mathbf{1 1 8 3}$ & $\mathbf{6 2}$ \\
\hline
\end{tabular}

Source: International labour Organisation Estimates and projections of the economically active population: 1980-2020 (fifth edition, August 2008), available at http:/ / laborsta.ilo.org, data downloaded 19 January 2009.

Table 4 Urban population as $\%$ of total population 1950-2010

\begin{tabular}{rrrrr}
\hline Year & More developed & Less developed & Least developed & World \\
\hline 1950 & 52.5 & 19.4 & 7.3 & 29.1 \\
1970 & 64.6 & 26.9 & 13.1 & 36.0 \\
1990 & 71.2 & 37.2 & 21.0 & 43.0 \\
2000 & 73.1 & 42.6 & 24.8 & 46.6 \\
2010 & 75.0 & 48.1 & 29.4 & 50.6 \\
\hline
\end{tabular}


International comparisons of wages are bedevilled by the need to find units of comparison across vastly different social and economic contexts, but Ashenfelter and Jurajda (2004) have proposed an ingenious answer to this problem by analysing the wages paid for the almost identical jobs done by McDonald's restaurant food preparation staff in capital cities in different countries. The Japanese 'McWage' is no less than 27 times its Indian counterpart. Adjusted for 'Big Macs per hour' (the number of another virtually identical product that can be purchased with an hour of the McWage) the differential falls to about 13, and adjusted for purchasing power parity using the World bank's world development indicators, it is six.

It thus seems clear that wage differentials between developed and developing states now are three to seven times as large as those between the old and new worlds in the previous age of mass migration. Moreover, within developed OECD countries, McWages differ little. This paradox is easily explained by immigration controls. McDonalds employees in India, China or Columbia cannot enter Japan, the EU or USA, while migration between advanced states is much easier. They must continue to work three of four hours to earn enough for the same Big Mac that their counterparts in developed countries achieve in a little over twenty minutes.

Debate over the significance of migration often hinges on comparing the impact upon developing countries of the 'brain drain' represented by such immigration, compared to the benefits it may offer them, especially in terms of the remittances sent by migrants, which at up to half a trillion dollars annually represent by far the biggest flow of resources from richer to developing countries. Also important are what have been called 'social remittances': the diffusion of new ideas, attitudes, behaviours, products, information, and technology facilitated by migration. However, as Pritchett (2006) has argued, it has been rich states ability to prevent the kind of migration that established the New World in the decades up to 1914 that locks most of the global proletariat out of equal participation in contemporary world capitalist development in what he terms 'everything but labour' globalisation. Estimates of the economic impact of liberalising labour migration depend upon too many assumptions to be precise, but even marginal changes, enough to increase rich states' labour forces by three per cent, would bring estimated annual benefits of at least one third of a trillion dollars to workers from poor countries. 
The McWage in developed countries is so high relative to others, not only because most of the global proletariat are excluded, but because post-industrial economies generate not only highly skilled employment, but what Baumol (1967) termed 'technologically non-progressive activities': service work that can neither be automated nor, typically, performed remotely from the site of its consumption because it requires the physical presence of the person providing it rendering it 'nontradable' (e.g. cleaning). As Marx (1976) described in his General Law of Capitalist Accumulation, as technological innovation displaces labour, it flows to sectors where such innovation is not possible. Someone must be there to hand over your Big Mac, while bank teller operations can be undertaken by a cash dispensing machine, or call centres located anywhere in the globe. Such non-tradable service activities are concentrated in personal care, or reproduction, which takes us back to the starting point of this chapter.

\section{The Global Reproductive Revolution}

Stand outside a school in Barcelona and you will see large numbers of mothers from Peru, Mexico, Ecuador and other Latin American countries taking the children to school. However it is not their own children they bring, the latter are usually still in Latin America. They are 'Canguros': childminders. Others care for the elderly or work in such occupations such as cleaning, retailing or catering. Spain stands out since illegal migration there from Latin America is facilitated by the low risk of deportation, the high chance of regularization, and a common language, while the dearth of public services for either child or elder care increases the private demand for such reproductive work. According to the Labour Force Survey (which may well undercount undocumented workers) over a million such women have arrived there since 2000, three quarters of them aged from 16 to 54 .

Both such migration and the changes in mortality and fertility we have considered earlier can be seen as part of the final, global stages of the general reproductive revolution which has accompanied the rise of modernity. Migration within states is linked to international migration, insofar as the move to urban centres may be the first stage in international migration, and both are driven by the development of the global market. The expansion of the latter, in turn is bound up with the shift of resources from the reproduction of people to the production of commodities made 
possible by the reproductive revolution. Meanwhile the expansion of population made possible by the latter in its early stages has produced what can be seen as a global workforce. Domestic and international migration can be seen as the result of the ability of capital to draw the surplus population released by this processinto both the production of goods and reproduction of people.

Zelinksy (1971) outlined a theory of what he called 'the mobility transition'. Social and spatial mobility is first stimulated by uneven economic development, such as the concentration of industry in urban centres, or the process of colonisation of 'virgin' territories by the imperial powers. As the demographic transition advances, lowering the increase in surplus population, the focus of mobility shifts towards the redistribution of the population within the economically more developed areas, so that for example, population declines in inner city areas, suburban sprawl develops, rural depopulation comes to an end, until ultimately mobility becomes predominantly a function of the rise and decline of different sectors of the economy and the relative attractiveness of different spatial locations in a world with little surplus population to be drawn into the system, since the latter has become global: what he called 'the super-advanced society of the future'.

In a sense Zelisnky was only filling in some of the empirical detail to Marx and Engel's precocious portrait, over a century earlier, of the creation of a global capitalist system which was subjecting the country to the rule of the towns and drawing barbarian nations into civilisation, using raw materials 'drawn from the remotest zones' for products to be consumed, 'in every quarter of the globe' and smashing all 'fixed, fast-frozen relations, with their train of ancient and venerable prejudices and opinions' (Marx and Engels 1976: 486-9). However Zelinsky's theory draws greater attention than their simpler formulation to the relationship between reproduction and production. A further step in such theorisation was the work of Cabré (1999) on the demographic history of Catalonia, which showed how the reproduction of population in this region of Spain had from an early stage depended heavily on in-migration. In this sense the earlier demographic history of Catalonia serves as a precursor to what has become the emergence of a new global pattern to the reproduction of population: with one exception. Just as towns usually drew no barriers around themselves to migration (although at times this was attempted in 
Russia and China) there was no frontier between Catalonia and the destitute agrarian Spanish hinterland on which it drew.

The global fall of fertility, and rise in life expectancy can be seen as perhaps the most revolutionary shift of all, since it at once undermines one of the most important roots of patriarchy, while at the same time liberating a tremendous proportion of social effort previously devoted to reproduction to for use in production, analogous to the way in which the revolution in agricultural productivity released labour from the countryside for work in industry, or de-industrialisation enabled the growth of the service sector (MacInnes and Pérez 2009b). The way in which this revolution produced a period of rapid global population growth, made possible the creation of a truly global market system and expanding world proletariat in the final two decades of the last century. For a few decades to come this new system will continue to be characterised by the both domestic and international migration flows as the surplus population created by the early stages of the reproductive revolution is drawn towards the centres of economic development.

However, as fertility continues to fall, and the economies of Asia and Latin America continue to expand, the size of this surplus population, and the migration flows associated with it, will reduce rapidly. Meanwhile, both the male breadwinner system, and other forms of gender inequality in production and reproduction will continue to be undermined, first by the declining relevance of the social regulation of fertility, and later by the declining weight of specifically reproductive work in society as a whole. At the same time, as lifespans continue to increase, and the years of healthy of life available after retirement rise steadily, issues of intergenerational equity will become more important. In the longer term, the global capitalist system will at some point in the future run out of surplus population for the first time in its history. Henceforth its ability to generate such a surplus will indeed depend upon its ability to slough off labour from established sectors of production faster than it can be absorbed by newly emerging ones. The probable considerable tightening of the global labour supply might augur well for further social progress.

Of course the actual course of such development will depend on all manner of unpredictable empirical change. Much will depend on whether a way is found to liberate Africa from its political, economic and demographic prison, and on whether the institutions of global trade and commerce manage the shift in economic power 
from the North to the East without either collapsing or veering towards some post cold war system of economic blocks.

The population of Europe is already dependent on immigration to continue rising, and it looks as if the world population itself will likely soon reach a maximum at around 9 billion (Lutz 2004). Mortality will continue to fall, but it is far from clear where its limits lie (Olshansky, Carnes y Cassel 1990; Wilmoth 1997; Wilmoth et al. 1999, 2000). Already more than half of the world's population of those over 65 live outside more developed countries. The proportion of what are sometimes called the 'oldest old', those over 80, will grow rapidly, so that on current projections, the world will have over 400 million octogenarians by 2050, three quarters of whom will live in what are today classed as less or least developed countries. However it is unclear what extra demand, if any, this will place on health and welfare systems. As long as healthy life expectancy (something intrinsically more difficult to measure than the span of life itself) continues to increase with life expectancy, and morbidity continues to be concentrated in the final years of life, then there may be little extra demand. Conversely, to the extent that new interventions become possible to combat the very different patterns of mortality and morbidity found in populations with longer lifespans, and to the extent that older people demand higher standards of healthy living made possible by new treatments and technologies, then demand may increase greatly.

Nor is the future course of fertility clear. In contrast to the fears expressed by many demographers that fertility might have no lower limit, and that rapid population decline be in prospect for many countries in Europe or elsewhere, few have noticed that since before the turn of the century, fertility has been rising almost everywhere in Europe, and in other affluent countries too. However the course of history will be shaped by the development for the first time of a global reproductive system with no surplus population to colonise. This might further increase the pressure towards gender equality, made possible by the reproductive revolution, analogous to the way in which the long boom of 1945 to 1973 eroded the foundations of the male breadwinner system in North America and Europe. Insofar as it does so, humankind will leave behind what we might think of as the pre-history of reproduction and with it the greatest of all 'ancient and venerable prejudices'. 


\section{References}

Ashenfelter, O and Jurajda, S. 2004. 'Cross-Country Comparisons of Wage Rates: The Big Mac Index', Unpublished manuscript, University of Princeton. Available at www.cerge.cuni.cz/news/ data/McWage\%20Index.pdf

Baumol W. J. 1967. 'Macroeconomics of unbalanced growth: the anatomy of urban crisis', The American Economic Review, 157: 415 - 426.

Becker, G. S. 1991. A Treatise on the Family. Cambridge, Mass.: Harvard University Press.

Billig, M. 1995. Banal Nationalism. London: Sage.

Bongaarts, J. 2008. 'Fertility Transitions in Developing Countries: Progress or Stagnation?', Studies In Family Planning, 39(2): 105-110.

Caldwell, J. C and Caldwell, P. 1986. Limiting Population Growth and the Ford Foundation Contribution. London: Frances Pinter.

Cabré i Pla, A. 1999. El sistema català de reproducció. Cent anys de singularitat demogràfica. Barcelona: Edicions Proa.

Carr-Saunders, A. M. 1922. The Population Problem: A Study in Human Evolution. Clarendon: Oxford.

Castles, S. and Miller, J. 2003. The Age of Migration $3^{\text {rd }}$ ed. Basingstoke: Palgrave

Chesnais, J.-C. 1992. The Demographic Transition: Stages, Patterns and Implications (Tr. Elizabeth and Philip Kraeger). Oxford: Clarendon Press.

Cleland, J. \& Wilson, C. 1987. 'Demand Theories of the Fertility Transition: an Iconoclastic View', Population Studies, 41( 1): 5-30.

Cleland, J. 2001. 'The Effects of Improved Survival on Fertility: A Reassessment', Population and Development Review, Supplement: Global Fertility Transition. 27: 6092.

Coale, A. J. and Waltkins, S. C. (eds) 1986. The Decline of Fertility in Europe. Princeton University Press.

Demeny, P. 2003. Population Policy: A concise Summary. Population Council Policy Research Division Working Paper no 173.

Dumont, G.F. 2008. 'Les conséquences géopolitiques de «L'hiver démographique » en Europe', Geéostratégiques 20:29-46.

Dupâquier, J. and Dupâquier, M. 1985. Histoire de la demographie. Paris: Librairie Academique Perrin.

Ehrlich, P. 1968. The Population Bomb. NY: Ballantine.

Finkle, J.L. and McIntosh, A.C. 2002. 'United Nations Population Conferences: Shaping the Policy Agenda for the Twenty-first Century', Studies in Family Planning 33 (1) 11-23.

Freeman, R. 2005, ‘What Really Ails Europe (and America): The Doubling of the Global Workforce' the Globalist, June 3.

Foucault, M. 1989. Sécurité, territoire et population. Résumé des cours. París: Julliard. 
Gilbert, G. 2005. World Population. 2nd ed. Oxford: ABC-CLIO.

Glass, D.V., 1936. The struggle for population. Oxford: Clarendon Press.

Hajnal, J. 1965. 'European Marriage Patterns in Perspective' in D.V. Glass y E.C. Eversley (eds) Population in History. London: Edward Arnold, 101-143.

Hatton, T. and Williamson, J. 1998. The Age of Mass Migration: Causes and Economic Impact. Oxford: Oxford University Press.

Henry, L. 1956. Anciennes familles Genevoises. Paris: INED.

Henry, L. 1965. 'Réflexions sur les taux de reproduction', Population (French Edition), 1: 53-76.

Hodgson, D. 1983. 'Demography as social science and policy science', Population and Development Review 9:1-34.

Hodgson, D. 1988. 'Orthodoxy and revisionism in American demography', Population and Development Review 14:541-569.

Kenealy, A. 1920. Feminism and Sex Extinction. London: T. Fisher Unwin

Kuhn, T. S. 1962. The Structure of Scientific Revolutions. Chicago: University of Chicago Press.

Landry, A. 1934. La révolution démographique. Paris: Sirey.

Laslett, P. 2000. The World We Have Lost: further explored. London: Routledge.

Le Bras, H. 1991. Marianne et les Lapins: l'obsession démographique. Paris: O. Orban.

Le Bras, H. 1998. Le Démon des Origines. Paris: Éditions de l'Aube.

Lee, R. 1981. 'Short term variation: vital rates, prices, and weather', in J.A. Wrigley and R. S. Schofield (eds), The Population History of England, 1541-1871. Cambridge, MA: Harvard University Press.

Lee, J. and Feng, W. 1999. 'Malthusian Models and Chinese Realities: The Chinese Demographic System 1700-2000', Population and Development Review, 25(1):33-65.

Livi-Bacci, M. 2001, A concise History of World Population $3^{\text {rd }}$ Ed. Oxford: Blackwell.

MacInnes, J. and Pérez, J. 2007. 'Low Fertility and Population Replacement in Scotland', Population Space and Place 13(1):3-21.

MacInnes, J. and Pérez, J. 2009a 'Demography', in Bryan Turner (ed) The New Blackwell Companion to Social Theory. Oxford: Blackwell.

MacInnes, J. and Pérez, J. 2009b. 'The Reproductive Revolution', Sociological Review 57(2) 262-84.

MacKenzie, D. 1976. 'Eugenics in Britain', Social Studies of Science: 499-532.

MacKenzie, D. 1981. Statistics in Britain 1865 - 1930:The Social Construction of Scientific Knowledge. Edinburgh: Edinburgh University Press.

Malthus, D. 1970. An Essay on the Principle of Population (Anthony Flew, editor). Harmonsdsworth: Pelican Books, 1970. 
Marx, K. and Engels, F. 1976. 'Manifesto of the Communist Party' [1848] in K. Marx \& F. Engels, Collected Works Vol. 6. London: Lawrence and Wishart.

Marx, K. 1976. Capital Vol. 1. Harmondsworth: Penguin.

Mosisa, A. I. 2002. 'The role of foreign-born workers in the U.S. economy', Monthly Labor Review. May, 3-15.

Myrdal, A. (1968 [1939]). Nation and Family. Cambridge Mass., M.I.T Press.

Olshansky, S. J., Carnes, B. A., and Cassel, C. 1990. 'In search of Methuselah: estimating the upper limits to human longevity', Science 250:634-640.

Omran, A. R. 1971. 'The Epidemiologic Transition: A Theory of the Epidemiology of Population Change', The Milbank Memorial Fund Quarterly, 49: 509-38. Reprinted in The Milbank Quarterly, 83: 731-57. (2005).

Polanyi, K. 1944. The Great Transformation. Boston. MA: Beacon Press

Potts, L. 1990. The World Labour Market: A History of Migration. London: Zed Books.

Pritchett, L. 2006. Let Their People Come. Washington: Center for Global Development.

Robinson, W. C. 1997. 'The Economic Theory of Fertility Decline Over Three Decades', Population Studies, 51: 63-74.

Ryder, N. B 1964. 'Notes On The Concept Of A Population', American Journal Of Sociology, 69 (5): 447-463.

Sauvy, A. 1959. La montée des jeunes. Paris: Calmann-Lévy.

Schultz, T. P. 1985. 'Changing world prices, women's wages, and the fertility transition', Journal of Political Economy, 93: 1126-54.

Soloway, R. A. 1990. Demography and Degeneration: Eugenics and the Declining Birthrate in Twentieth-Century Britain. Chapel Hill: Universtity of North Carolina Press.

Spengler,O. 1926. The Decline of the West. Allen and Unwin: London.

Szreter, S. 1993 'The Idea of Demographic Transition and the Study of Fertility Change', Population and Development Review, 19: 659-702.

Szreter, S. 1996. Fertility, Class and Gender in Britain, 1860-1940. Cambridge: Cambridge University Press.

Teitelbaum, M.S, and Winter, J. 1985. The Fear of Population Decline. London: Academic Press.

Thompson, W. 1929. 'Population', American Journal of Sociology, 34: 959-75.

Torpey, J. 1999. The Invention of the passport. Cambridge: Cambridge University Press.

Urry, J. 2000. Sociology beyond societies: mobilities for the twenty-first century. London: Routledge.

Willcox , W. F. 1916. 'The nature and significance of the changes in the birth and death rates in recent years,' American Statistical association. New Series, No. 113, March. 
Wilmoth, J. R. 1997. 'In Search of Limits', in K.W. Wachter and C.E. Finch (eds) Between Zeus and the Salmon: The Biodemography of Longevity. Washington, DC: National Academy Press.

Wilmoth, J. R. and Horiuchi, S. 1999. 'Rectangularization Revisted: Variability of Age of Death Within Human Populations', Demography, 36 (4): 475-496.

Wilmoth, J. R., Deegan, L. J., Lundstrom, H. and Horiuchi, S. 2000. 'Increase of maximum life-span in Sweden, 1861-1999', Science, 289:2366-8.

Zelinsky, W. 1971. 'The hypothesis of the mobility transition', The Geographical Review, 2. 